JOURNAL

OF TOURISM

AND ECONOMIC
Journal of Tourism and Economic Vol.3, No.2, 2020, Page 66-76

ISSN: 2622-4631 (print), ISSN: 2622-495X (online)

Email:jurnalapi@gmail.com

Website: http://jurnal.stieparapi.ac.id/index.php/JTEC

DOI: https://doi.org/10.36594/jtec.v3i2.99

\title{
DETERMINING PRIORITY NEEDS OF CULINARY MICRO-ENTERPRISE CUSTOMERS IN INDONESIA THROUGH A QUALITY PERSPECTIVE
}

\author{
Tutur Wicaksono \\ Szent István University Hungary \\ tuturwicaksono18@gmail.com \\ Rika Fatimah P.L \\ Universitas Gadjah Mada Indonesia
}

\begin{abstract}
Determining the priority of customer needs is one of the right steps for business people to take to determine the direction of allocating their resources. In this study, affinity diagrams and tree charts are used to classify and translate the opinions of loyal customers about customer needs. The customer opinion (voice of the customer) obtained through semistructured interviews is then translated into a technical language (voice of quality) that has a relationship and correlation to existing theories. Data in the form of items of customer need, which are the result of affinity diagram analysis and tree diagrams, are then presented using a matrix that takes the left and right chamber of the House of Quality (HOQ) matrix from the Quality Function Deployment (QFD) method. Matrix that adopts the left and right chamber of HOQ matrix will display the items of customer needs and their priority level. The purpose of this study is to identify the item of customer needs and determine the priority level of customer needs for micro culinary fried rice enterprise in Indonesia. The variable Service Quality in the dimension of Responsiveness with the indicator item Fast Service ranks third. Variable Perceived Benefit in the dimension A Statement of Value with items including Low Prices and Discount occupy the second position. The variable of product quality in the Performance dimension with items including Delicacy, High Quality Ingredients, Varied Menu and Large Portion is the variable of customer needs with the highest priority.
\end{abstract}

Keywords: SMEs, Business, QFD, House of Quality, Culinary

\section{INTRODUCTION}

According to Statistics Indonesia, it shows that the percentage of the SME population in Indonesia reaches $99.9 \%$ and contributes $60 \%$ of the IDR $12,840.4$ trillion of Indonesia's GDP and more than a third are engaged in the culinary sector. This shows that the SME sector makes a significant contribution to the economic system in Indonesia. According to the Statistics Indonesia Publication, data on local rice consumption in Indonesia in 2018 reached $1,504 \mathrm{~kg}$ per capita per week. This assumes that the Indonesian population has a fairly high level of consumption of rice / culinary based on rice (Badan Pusat Statistik, 2019). One example of a typical Indonesian culinary product that is known internationally is 
fried rice. $\mathrm{CNN}$ Indonesia published articles about the 50 tastiest foods in the world which were determined through 35,000 votes on Facebook social media, and the result was fried rice from Indonesia was ranked as the second most delicious food under rendang (CNN Indonesia, 2017). The idea of initiating a micro culinary fried rice business can be the right business idea, but the limited resources available to be used by microindustry entrepreneurs have caused them to try hard to survive in the competition, therefore business actors must be able to allocate resources effectively and efficiently (Pribadi et al, 2017). Determining the priority of customer needs can help entrepreneurs know what things can be prioritized from indicators of various customer needs so that the use of company resources can be channeled effectively and efficiently to produce what is in accordance with customer needs, thus it is hoped that products can be absorbed more quickly in the market so that it has an impact on faster business growth. This research was conducted to identify customer needs and find out how the priority level of micro culinary fried rice enterprises in Indonesia. We consider that the use of affinity diagrams and tree diagrams is the right method to use in this study. Based on the formulation of the problem and the research background above, we compiled two research questions. The first research question is "what is the customer needs for the micro culinary fried rice enterprise in Indonesia?" and the second research question is "how is the priority level of customer needs for the micro culinary fried rice enterprise in Indonesia?".

\section{LITERATURE REVIEW}

\section{Micro-enterprises}

Micro-enterprises are productive businesses owned by individuals, and / or individual business entities which have a net worth of not more than $\mathrm{Rp}$.
$50,000,000.00$ (fifty million rupiahs), excluding land and buildings for business premises, or having an annual turnover of at most Rp. 300,000,000.00 (three hundred million rupiah) (Pemerintah Indonesia, 2009). According to Lockwood (2013) micro-enterprises or micro businesses are simply local people who use their talents and skills creatively to deliver assistance and services that are beneficial to local communities and their communities. Booyens (2011) states that microenterprises have up to four employees where the owner of the business is one of them. Lockwood (2013) also explains that micro-enterprises operate on a very small scale, usually providing direct services with the support of a very small number of people who work as employees or employed volunteers. According to Sharma et al (1990) in their research, it is stated that micro-enterprises play an important role in the development and growth of local and regional economies by creating employment and commercialization of innovations that produce economic growth. Microenterprises can contribute significantly to the socio-economic development of lowincome households ensuring sustainable economic growth (Al Mamun \& Fazal, 2018). One of the business sectors that is considered promising is business in the culinary sector because food is one of the basic human needs (Zuari et al, 2013). The food and beverage service business is included in the tourism business, what is meant by food service business in this law is a food and beverage service business equipped with equipment and equipment for manufacturing, which can be in the form of restaurants, cafes, catering services, and bars or taverns (Pemerintah Indonesia, 2009).

\section{Culinary}

The term culinary originates from Latin, namely culinarius, which means material related to the cooking process. Culinary can be interpreted as a patron of 
usage which comes from food or dishes (Akbar and Pangestuti, 2017). According to Rahman (2018), the creation of culinary itself is a reflection of various perceptions of Indonesianness. Since its inception, Indonesian culinary delights are a mixture of various regional and foreign cultures. Indonesia, which has a variety of distinctive culinary delights, is expected to give a good image and attract foreign tourists. Today the culinary business produces products that no longer only fulfill its function as hunger relief but also as a tool to fulfill the overall satisfaction of customers through preparation, processing, presentation of food and beverage products that make elements of creativity, aesthetics, tradition and / or local culture; as the most important element in increasing the taste and value of these products, to attract purchasing power and provide an experience for customers called culinary (Lazuardy and Triady, 2015). As previously mentioned, one of the most well-known Indonesian cuisines in the world is fried rice. Fried rice can be found all over Indonesia so that it becomes a characteristic of Indonesian national culinary which is known by the international community. In general, fried rice has similar basic ingredients, namely garlic, rice, and soy sauce. However, there are other variations used for seasoning, for example the use of dried shrimp (ebi), curry, tomatoes, shrimp paste, spices, and chilies. Variations of fried rice can also be found in the selection of complementary ingredients such as the use of vegetables, sausages, chicken, eggs, mutton, beef and fish (Tyas, 2017).

\section{METHOD, DATA, AND ANALYSIS}

This research uses a mix method, descriptive. This study uses qualitative data items of opinion results from semistructured in-depth interviews with loyal customers about their needs for the micro culinary fried rice enterprise (micro-street vendor). The quantitative data used in this study are derived from sum of the results of the questionnaires on the weights of items of customer needs that are calculated using a Likert scale to determine the priority level of customer needs. The results of a study can be used as consideration for the company's business decision making (Sekaran and Bougie, 2016). The core of this research is to determine the priority needs of customers from micro culinary fried rice enterprises in Indonesia. The research location is in Pamulang, South Tangerang City, Banten Province, Indonesia. In this study, one of the primary data sources is data from interviews. The type of interview conducted was a semi-structured in-depth interview with eight loyal customers of micro culinary fried rice enterprise in Indonesia to provide informations about what the customers need for the micro culinary fried rice enterprise (Voice of Customers). Other primary data is in the form of quantitative data obtained through distributing questionnaires to 248 respondents of micro culinary fried rice enterprise customers in Indonesia. The steps to determine the number of loyal customers to be interviewed in this study were carried out by randomly selecting 8 micro culinary fried rice enterprise in Pamulang, Indonesia, then each micro culinary fried rice enterprise will recommend one loyal customer to be interviewed. The importance of selecting qualitative data from loyal customers is because loyal customers have a deep commitment to re-subscribe or provide consistent re-purchase of selected products or services in the future, even though the situation and marketing efforts have the potential to cause behavior change (Hurriyati, 2010). Loyal customers have good knowledge about the customer's needs for the product to be studied. Loyal customers who will be interviewed are customers who have purchased fried rice at the same outlet more than five times. Questionnaire also used to obtain data on the priority level of customer needs. Each 
respondent was asked to fill in the importance weight of each item of customer needs in the questionnaire. The statement items in the questionnaire are voice of customers obtained from the interview process with loyal customers and analyzed with affinity diagrams and tree diagrams. The questionnaire was filled by the respondents at eight micro culinary fried rice enterprise outlets in Indonesia.

The interview resulted a large amount of random, abstract data. The data is then grouped by looking at the similarity of characteristics between the data so that it becomes a group of data that has a relationship in each group, using an affinity diagram. Tree diagrams are also used to translate the opinions of customers (Voice of Customers) into technical language (Voice of Quality). Tree diagram can be used to translate customer language into language types that have something to do with the quality applied in the system, organization and management itself (Fatimah et al., 2007). House of Quality (HOQ) matrix from the Quality Function Deployment (QFD) method will be used in this study to present the results of the final analysis. According to Fatimah et al. (2007), Quality Function Deployment (QFD) method was developed to satisfy needs by translating customer needs into the company's production process. The Quality Function Deployment analysis method has an analysis tool called the House of Quality (HOQ), which is a graphic technique to define the relationship between customer desires and a product (or service) to map conditions in the business world (Heizer \& Render, 2014). The HOQ-Matrix helps to identify technical components that need to be changed. This ensures that all measures of the company are based on customer needs. This process begins with the identification of customer needs and the subsequent implementation of a competitive analysis (De Pelsmaeker et al., 2015). Mapping results are represented by components in the House of Quality. This study only adopts two components of HOQ, which is the left chamber and the right chamber HOQ. There are six components in the formation of the House of Quality matrix, the component is in the form of a chamber to answer research questions, which includes the left chamber, the right chamber, the upper chamber, the lower chamber, the middle chamber and the attic chamber (Heizer \& Render 2014). This study will use only 2 components, which is the left chamber and right chamber of the House of Quality. 


\section{ANALYSIS AND RESULT}

\section{Affinity Diagram Result}

Fig 1. Results of affinity diagram analysis on the needs of micro culinary fried rice enterprise customers in Indonesia

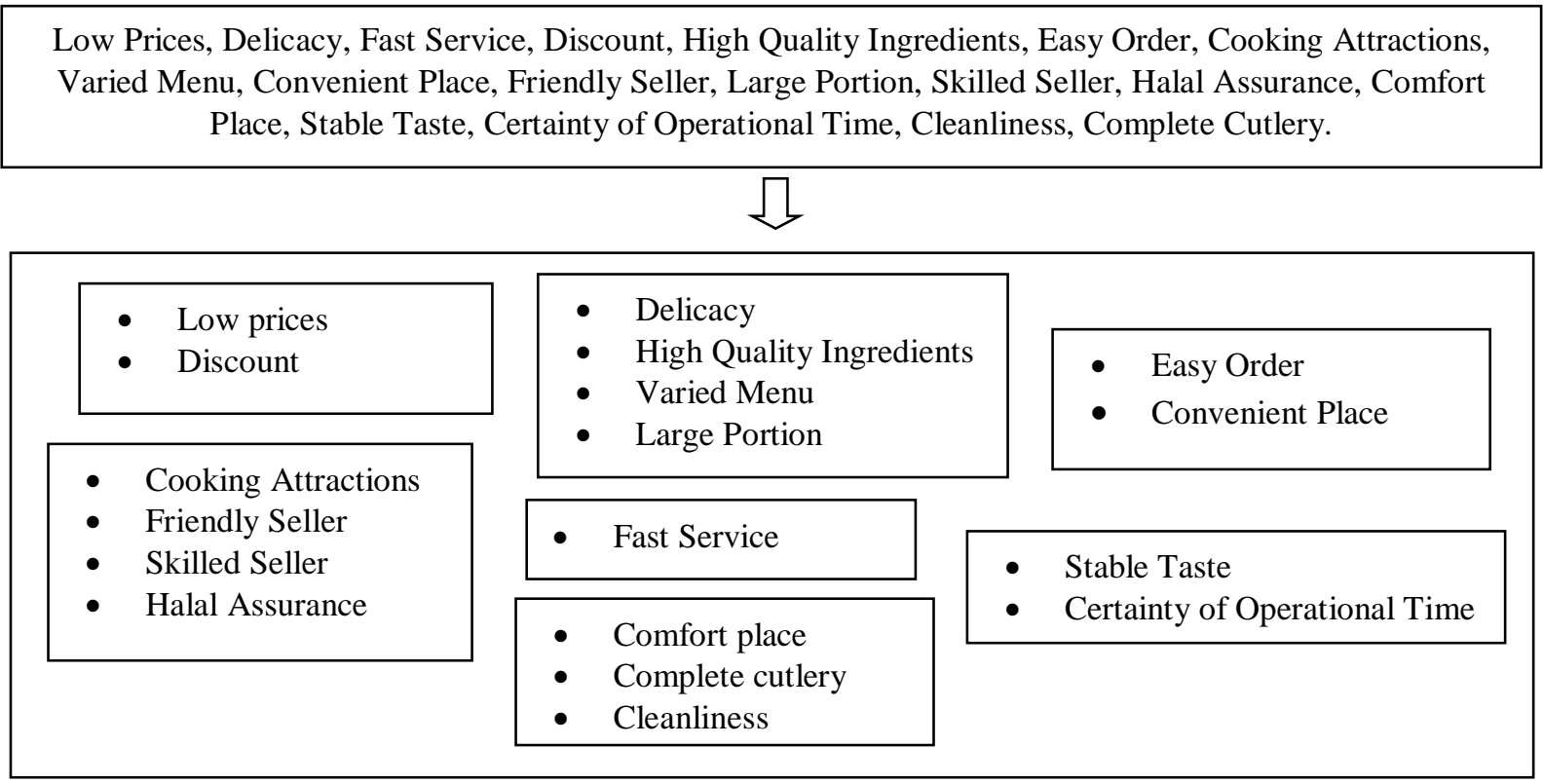

(source: author's analysis, 2019)

This research involved eight informants who are loyal customers of micro culinary fried rice enterprises in Indonesia. The interview process with eight loyal customers resulted in 18 item indicators regarding what customers needed from the micro culinary fried rice enterprises in Indonesia which is, Low prices, Delicacy, Fast Service, Discount, High Quality Ingredients, Easy Order, Cooking Attractions, Varied Menu, Convenient Place, Friendly Seller, Large Portion,
Skilled Seller, Halal Assurance, Comfort Place, Stable Taste, Certainty of Operational Time, Cleanliness, Complete Cutlery. A verbal data analysis was conducted using an affinity diagram to answer the first question of this study, which is "what is the customer needs for the micro culinary fried rice enterprise in Indonesia?". The results of the affinity diagram analysis of this study can be seen in Figure 1. 


\section{Tree Diagram Analysis Result}

Fig 2. Results of tree diagram analysis on the needs of micro culinary fried rice enterprise customers in Indonesia

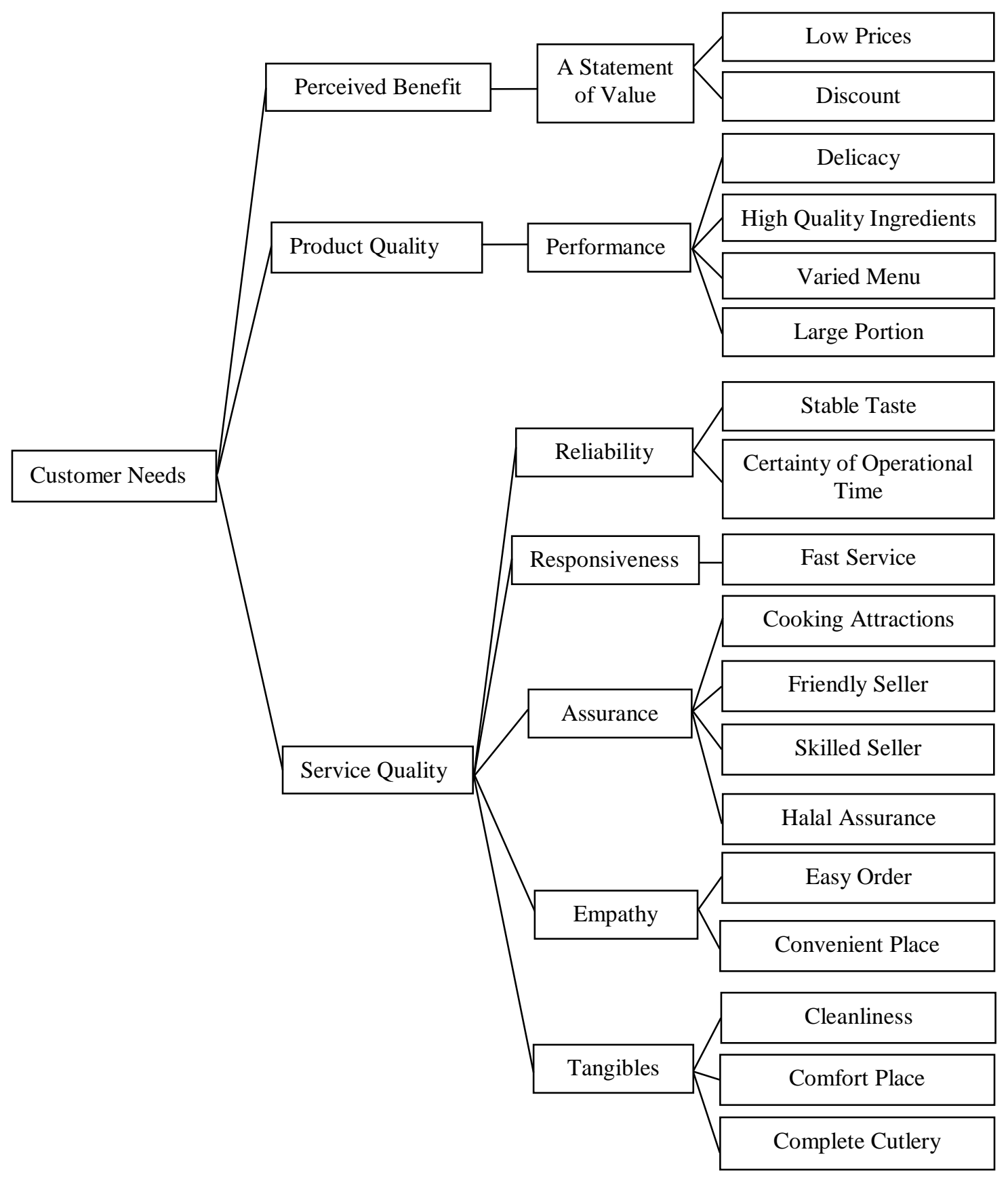

(source: author's analysis, 2019)

The items Low Prices and Discount in this study are grouped into the dimensions of A Statement of Value, which is one of five factors affecting customer perceptions of the product; this was explained by Sugianto and Sugiharto (2013). Price is a statement of a product's value (a statement of value). value is the ratio or comparison between perceptions of perceived benefits and costs incurred to get product value, the price will shape customer perceptions about how worthy this product is 
purchased, so the price will affect to determine the customer in buying the product (Tjiptono, 2011)

The items Delicacy, High Quality Ingredients, Varied Menu and Large Portion have relevance and similarity in characteristics. This study is grouped into the Performance dimension, which is a variable of Product Quality, and this is explained by Tjiptono (2010) that the Performance dimension relates to the functional aspects of an item and is the main characteristic that considers customers in buying the item. Items Stable Taste, and Certainty of Operational Time have relevance and similarity of characteristics, which are grouped into the dimension of Reliability, that reliability includes two main things, namely, work consistency (performance) and the ability to be trusted (dependability). This means that the company provides its services right from the first time. It also means that the company concerned is fulfilling its promise. According to Parasuraman et al. (1988), reliability can carry out service promises reliably and precisely. Items Fast Service have relevance and similarity in properties, in this study grouped into the dimension of responsiveness. Responsiveness involves good service and a high level of participation and adaptability, namely helping to solve problems immediately. According to Parasuraman et al. (1988), responsiveness is the willingness to help customers and provide fast service. The items Cooking Attractions, Friendly Seller, Skilled Seller, and Halal Assurance have relevance and similarity in characteristics in this study grouped into the Assurance dimension.

According to Tjiptono (2011), the Assurance dimension covers business people's behavior who can create trust and provide a sense of security for customers. Forms of assurance include employees being friendly, polite, and having all the skills needed to serve every customer. The items Easy Order and Convenient Place have the relevance and similarity of traits in this study grouped into the Empathy dimension. According to Parasuraman et al. (1988), empathy includes a sense of care and its attention to each customer. Items of Cleanliness, Comfort Place and Complete Cutlery have relevance and similarity in the characteristics of this study grouped into the dimensions of Tangibles. Tangibles includes the physical form of service providers, including building infrastructure, location, and shape of goods, the convenience of infrastructure, modern tools, and equipment. Reliability, Responsiveness, Assurance, Empathy, and Tangibles are dimensions of Service Quality variables that are often used as benchmarks for companies' service capabilities in meeting the needs and expectations of their customers (Da Cruz Oliveira \& Kusnanta, 2018). It can be seen in Figure 2 that the tree diagram can translate customer language regarding customer needs into technical language and shows the relationship and correlation between items of customer needs and literary theory.

\section{Left Chamber Adoption of House of Quality Matrix Analysis}

Verbal data from interviews that have been analyzed using affinity diagrams and tree diagrams are then presented in a table that adopts the left chamber of the House of Quality matrix from the Quality Function Deployment method. It can be seen in the table below that this study produces three variables of customer needs. The first is Perceived Benefit with the dimension A Statement of Value with two indicator items, Low Prices and Discount. The second variable is Product quality, with the dimension being Performance with four indicator items including Delicacy, High Quality Ingredients, Varied Menu and Large Portion. The third variable is Service Quality with five dimensions. The first is the dimension of Reliability with two 
indicator items, namely Stable Taste, Certainty of Operational Time. The second dimension is Responsiveness, with the item being Fast Service. The third dimension is Assurance with four indicator items, including Cooking Attractions, Friendly Seller, Skilled Seller and Halal
Assurance. The fourth dimension is Empathy with two indicator items, namely Easy Order and Convenient Place. The fifth dimension is Tangibles with indicator items, including Cleanliness, Comfort Place, Complete Cutlery.

Table 1. HOQ matrix left chamber adoption: customer needs for micro culinary fried rice enterprise customers in Indonesia

\begin{tabular}{|c|c|c|c|}
\hline \multirow{14}{*}{ 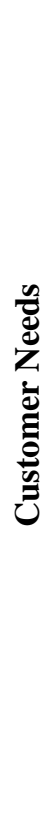 } & Variables & Dimensions & Attributes \\
\hline & Perceived Benefit & A Statement of Value & $\begin{array}{l}\text { Low prices } \\
\text { Discount }\end{array}$ \\
\hline & Product Quality & Performance & $\begin{array}{l}\text { Delicacy } \\
\text { High Quality Ingredients } \\
\text { Varied Menu } \\
\text { Large Portion }\end{array}$ \\
\hline & Service Quality & Reliability & $\begin{array}{l}\text { Stable Taste } \\
\text { Certainty of Operational Time }\end{array}$ \\
\hline & & Responsiveness & Fast Service \\
\hline & & Assurance & Cooking Attractions \\
\hline & & & Friendly Seller \\
\hline & & & Skilled Seller \\
\hline & & & Halal Assurance \\
\hline & & Empathy & Easy Order \\
\hline & & & Convenient Place \\
\hline & & Tangibles & Cleanliness \\
\hline & & & Comfort Place \\
\hline & & & Complete Cutlery \\
\hline
\end{tabular}

(source: author's analysis, 2019)

\section{Customer Needs Priority Matrix Analysis Adopting Right Chamber of HOQ}

The reliability test in this study will use the Cronbach Alpha statistical test method with the SPSS 25 program. This study's Cronbach alpha test attributes use SPSS 25, showing that each attribute has a Cronbach alpha value $>0.6$. This shows that the item used is reliable. This study's validity test used the correlation coefficient significance test using SPSS 25 for each questionnaire item with an initial sample of 60 respondents. The validity test results show that each item has a greater than $r$ table with a significance value of more than 0.05 , which indicates that each item used is valid. The research was continued by processing a total of 248 questionnaires that were collected. Quantitative data analysis was carried out by utilizing a matrix that adopts the right chamber of the HOQ matrix to answer the second question of this study, which is "how is the priority level of customer needs for the micro culinary fried rice enterprise in Indonesia?". The priority level of customer needs is obtained by calculating each attribute's average value obtained from the number of values per attribute divided by the number of attributes in the relevant variable. The priority of customer needs will fill the right chamber of the HOQ matrix. The calculation results are in the right chamber of HOQ, which shows the priority order of customer needs. Three variables of customer needs with the 
highest priority, among others, are the variable Service Quality in the dimension of Responsiveness with the indicator item Fast Service ranked third with an average value of the level of importance per variable of 4.375 . The variable Perceived Benefit in the dimension of A Statement of Value with items including Low Prices and Discount occupies the second position with an average value of the level of importance per variable of 4.451. Variable Product Quality in the dimension of Performance with items including Delicacy, High Quality Ingredients, Varied Menu and Large Portion are variables of customer needs with the highest priority with an average level of interest, per variable of 4.516 for micro culinary fried rice enterprises customers in Indonesia.

Table 2. HOQ matrix right chamber adoption: customer needs for micro culinary fried rice enterprise customers in Indonesia

\begin{tabular}{|c|c|c|c|c|c|c|}
\hline & Variables & Dimensions & Attributes & $\begin{array}{c}\text { Level of } \\
\text { Importance } \\
\text { Per Attribute }\end{array}$ & $\begin{array}{c}\text { Level of } \\
\text { Importance } \\
\text { Per Variable }\end{array}$ & $\begin{array}{c}\text { Priority } \\
\text { Needs }\end{array}$ \\
\hline & Perceived & A Statement of & Low prices & 4,544 & 4,451 & 2 \\
\hline & Benefit & Value & & & & \\
\hline \multirow{17}{*}{ 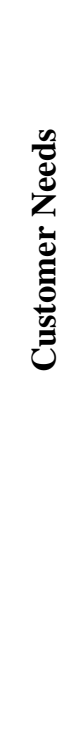 } & & & Discount & 4,359 & & \\
\hline & Product & Performance & Delicacy & 4,960 & 4,516 & 1 \\
\hline & Quality & & High Quality Ingredients & 4,597 & & \\
\hline & & & Varied Menu & 4,359 & & \\
\hline & & & Large Portion & 4,149 & & \\
\hline & & Reliability & Stable Taste & 4,040 & 4,129 & 7 \\
\hline & & & $\begin{array}{l}\text { Certainty of Operational } \\
\text { Time }\end{array}$ & 4,218 & & \\
\hline & Service & Responsiveness & Fast Service & 4,375 & 4,375 & 3 \\
\hline & Quality & & Cooking Attractions & 4,319 & 4,206 & 6 \\
\hline & & Assurance & Friendly Seller & 4,073 & & \\
\hline & & & Skilled Seller & 4,177 & & \\
\hline & & & Halal Assurance & 4,254 & & \\
\hline & & Empathy & Easy Order & 4,278 & 4,339 & 5 \\
\hline & & & Convenient Place & 4,399 & & \\
\hline & & Tangibles & Cleanliness & 4,383 & 4,355 & 4 \\
\hline & & & Comfort Place & 4,351 & & \\
\hline & & & Complete Cutlery & 4,331 & & \\
\hline
\end{tabular}

(source: author's analysis, 2019)

\section{CONCLUSION}

The first research objective is to identify customer needs for micro culinary fried rice enterprise in Indonesia. The answer is a table that adopts the left chamber of the House of Quality in this study. The analysis produces three variables. The first variable is Perceived Benefits, the second variable is Product Quality and the third variable is Service Quality. The second research objective is to determine priority level of customer needs for micro culinary fried rice enterprise in Indonesia. The answer is by adopting the right chamber from the House of Quality in this study. The right chamber of HOQ shows customer needs for micro culinary fried rice enterprise in Indonesia. Variable Product Quality in the dimension of Performance with indicator items including Delicacy, High Quality Ingredients, Varied Menu and Large Portion are variables of customer needs who occupy top priority with an average value of interest levels, per variable of 4.516. The variable Perceived Benefit in the dimension of A Statement of Value 
with items including Low Prices and Discount ranks second priority with an average value of the level of importance per variable of 4.451 . The variable Service Quality in the dimension of Responsiveness with the indicator item Fast Service is ranked third with an average value of the level of importance per variable of 4.375 .

\section{REFERENCES}

Akbar, A.T., Pangestuti, E. (2017). Peran Kuliner dalam Meningkatkan Citra Destinasi Pariwisata Taman Nasional Bromo Tengger Semeru. Jurnal Administrasi Bisnis, 50(1), 153-159.

Bps.go.id. (2019). Keadaan Angkatan Kerja Di Indonesia Februari 2019. Retrieved 2 February 2019, from https://www.bps.go.id/publication/20 19/05/31/a96ce41f72e59d5dfb1cad9 f/keadaan-angkatan-kerja-diindonesia-februari-2019.html.

Bps.go.id. (2019). Rata-Rata Konsumsi Per Kapita Seminggu Beberapa Macam Bahan Makanan Penting, 2007-2019. Retrieved 2 February 2019 , from https://www.bps.go.id/statictable/20 14/09/08/950/rata-rata-konsumsiper-kapita-seminggu-beberapamacam-bahan-makanan-penting2007-2019.html

Booyens, I. (2011). Are small, mediumand micro-sized enterprises engines of innovation? The reality in South Africa. Science And Public Policy, $38(1)$, 67-78. https://doi.org/10.1093/scipol/38.1.6 근

CNN Indonesia. (2017). Rendang \& Nasi Goreng Dipilih Jadi Makanan Terenak Di Dunia. CNN Indonesia. Retrieved 3 February 2019, from https://www.cnnindonesia.com/gaya- hidup/20170715172743-307228130/rendang-nasi-goreng-dipilihjadi-makanan-terenak-di-dunia .

De Pelsmaeker, S., Gellynck, X., Delbaere, C., Declercq, N., \& Dewettinck, K. (2015). Consumer-driven product development and improvement combined with sensory analysis: A case-study for European filled chocolates. Food Quality And Preference, 41, 20-29. https://doi.org/10.1016/i.foodqual.20 14.10.009.

Fatimah, P., Abdul Aziz, J., Anuar, M., \& Nasir, S. (2007). Quality_Marriage Deployment in determining priority needs for initiating marriage loyalty. Quality And Quantity, 43(3), 401416. https://doi.org/10.1007/s11135007-9115-1.

Heizer, J., \& Render, B. (2014). Operations Management: Sustainability and Supply Chain Management. $\quad 11^{\text {th }}$ ed. Essex: Pearson.

Hurriyati, R. (2020). Bauran Pemasaran dan Loyalitas Konsumen (3rd ed.). CV. Alfabeta.

Lazuardy, M. and Triady, M. S. (2015). Ekonomi Kreatif: Rencana Pengembangan Kuliner Nasional 2015-2019 [Ebook] (1st ed.). PT. Republik Solusi. Retrieved 6 February 2019, from https://www.academia.edu/27578681 /EKONOMI_KREATIF_Rencana Pengembangan_KULINER_Nasiona 1_2015_2019.

Lockwood, S. (2013). Micro- enterprise:. Journal Of Integrated Care, 21(1), 26-33. https://doi.org/10.1108/14769011311 305558.

Al Mamun, A., \& Fazal, S. (2018). Effect of entrepreneurial orientation on competency and micro-enterprise performance. Asia Pacific Journal 
Of Innovation And

Entrepreneurship, 12(3), 379-398. https://doi.org/10.1108/apjie-052018-0033.

Da Cruz Oliveira, M., \& Kusnanta, G. (2018). ANALISIS PENGARUH KUALITAS PELAYANAN TERHADAP KEPUASAN PELANGGAN PADA PERUSAHAAN TRANSPORTASI JASA PT. SRIWIJAYA AIR. Journal Of Tourism And Economic, 1(1).

https://doi.org/10.36594/jtec.v1i1.19.

Parasuraman, A., Zeithaml, V.A., \& Berry, L.L. (1988). Servqual: A MultipleItem Scale for Measuring Consumer Perceptions of Service Quality. Journal of Retailing, 64(1), 12-40.

Presiden Republik Indonesia. (2009). UU RI No 10 Tahun 2009 Tentang Kepariwisataan. Jakarta.

Pribadi, A., Alam, M.N., and Effendy. (2017). Analisis Pendapatan Usaha Roti Pada Industri Rumah Tangga Aisyah Bakery di Kota Palu. e-J. Agrotekbis, 5(4), 466-471.

Rahman, F. (2018). Kuliner Sebagai Identitas Keindonesiaan. Jurnal Sejarah, 2(1), 43-63.
Sekaran, U., \& Bougie, R. (2016). Research Method for Business: A Skill Building-Approach (7th ed.). J. Wiley.

Sharma, M., Miller H.G., and Reeder, R. (1990). Micro-Enterprise Growth: Operational Models and Implementation Assistance in Third and Fourth World Countries. Journal of Small Business Management, 921.

Sugianto, J., and Sugiharto, S. (2013). Analisa Pengaruh Service Quality, Food Quality, dan Price Terhadap Kepuasan Pelanggan Restoran Yung Ho Surabaya. Jurnal Manajemen Pemasaran Petra, 1(2), 1-10.

Tjiptono, F. (2011). Pemasaran Jasa (3rd ed.). Bayumedia Publishing.

Purwaning Tyas, A. (2017). Identifikasi Kuliner Lokal Indonesia dalam Pembelajaran Bahasa Inggris. Jurnal Pariwisata Terapan, 1(2), 38. https://doi.org/10.22146/jpt.24970.

Zuari, F.O., H. Widayani and Daniel, R.D. (2013). Pengaruh Strategi Pemasaran Terhadap Penerimaan Bersih Restoran Omah Pincuk. Proceeding PESAT, 5, 383-389. 